Australian Government Printing Service, 1980). The SCALE data bases now consist of the 1973 Consolidation of the Commonwealth Statutes, and subsequent annual legislation, the texts of the Australian Capital Territory Ordinances, and the Commonwealth Law Reports, vols. 128-138.

Australian Laze Librarians' Group Nezwsletter, No. 40

(October 1980), p. 5

\title{
COMPUTERIZED LEGAL RESEARCH IN EUROPE
}

Trade journals are reporting the development of a computerized legal research service by two British companies. Called Eurolex, the system is designed to retrieve information from the huge volume of case law, legislation and regulatory material originating in Europe, both national and European Community. BOC Datasolve limited a subsidiary of BOC International, Ltd., is providing the computer hardware and software, as well as the telecommunications facilities through which the service will be, in the jargon of the trade, accessed. The data base itself is being developed by European Law Centre Limited in London.

In the meantime Mead Data Central, producer of the LEXIS computerized legal information service in the United States, is expanding its data base to include English law. In conjunction with Butterworth, a major English law publisher, it is creating a data base for English legislation and case law which will be made available to all LEXIS subscribers on both sides of the Atlantic. Mead Data Central is also conducting negotiations for a similar service in Australia.

\section{FORD FOUNDATION GRANTS FOR LEGAL AND HUMAN RIGHTS WORK}

The Ford Foundation traditionally makes grants on a selective basis for training, research and publication projects which appear to promote the international advancement of law and justice. Readers may be interested in some recent grants of the Foundation in two intensively debated and publicized areas: human rights and the development of new legal systems.

\section{Human Rights}

Lawasia Research Institute (Australia), U.S. $\$ 25,000$, for its recently constituted standing committee on human rights in Asia and the Pacific. 
International Commission on Jurists (ICJ), U.S. $\$ 25,000$, to assist nascent human rights organizations in the Middle East and North Africa. ICJ also received U.S. $\$ 18,500$ for a follow-up to the Conference on Human Rights and Development, which it organized in Dakar in 1978. Funds will support final preparation of the conference's conclusions and their presentation to the Organization for African Unity.

International League for Human Rights, U.S. $\$ 12,000$, to develop means of assisting newly formed African human rights groups and to work with them toward the creation of an African Human Rights Commission.

Washington Office of Latin America (WOLA), U.S. $\$ 18,000$, to broaden its base of financial support in the United States and expand its contacts with religious, democratic, and human rights groups in Latin America. Such groups send WOLA first-hand information on incidents of torture, mass detention, and disappearances as well as violations of socioeconomic rights. WOLA publicizes this information through its bimonthly newsletter, and through contacts with the U.S. press, Congress, State Department, and international agencies.

Procedural Aspects of International Law Institute, U.S. $\$ 4,478$, for investigation of the human rights situation in Yugoslavia and Romania by the director of the institute's International Human Rights Law Group and two other attorneys.

Les Cahiers du Samizdat, U.S. $\$ 90,000$, three-year support of USSR News Brief, a biweekly that reports on arrests, trials, searches, and incarceration of Soviet citizens active in defense of human rights. Les Cahiers, based in Brussels, distributes News Brief in Both English and Russian, along with other samizdat-uncensored materials from the USSR. The grant will enable News Brief to update its list of Soviet prisoners of conscience and to compile a record of Soviet officials responsible for cruel treatment of prisoners.

Johns Hopkins University, U.S. $\$ 18,000$, transitional support of the Universal Human Rights Journal until the university press can assume its costs in 1982. The journal, noted for its international and interdisciplinary perspective, provides a link between scholarly research and public policies.

Human Rights Internet, U.S. $\$ 32,340$, to prepare a guide to human rights research material, widely scattered in libraries, universities, and organizational files.

Foundation for the Promotion of Social Sciences and Humanities Textbooks (Thailand), U.S. $\$ 25,000$ supplement, to help complete a research project on human rights in Thailand. Among the topics are criminal justice, rights of peasants, and sexual exploitation of Thai women.

\section{New Legal Systems-Zimbabwe}

To help the Ministry of Justice build a new judicial system, the Foundation recently granted the Government of Zimbabwe, U.S. $\$ 147,500$ 
over two years. The new judiciary will operate at four levels: village courts, for disputes involving small sums of money; community courts, in both rural and urban areas, for more complicated cases and for appeals from village courts; magistrates courts, for criminal and major civil cases and appeals from community court decisions; and the Supreme Court, for final appeals. Village and community court proceedings will be in tribal languages, and decisions will be based largely on customary law. Cases before the two higher courts will continue to be conducted in English.

Foundation funds will be used to train community court judges, some ten from each of Zimbabwe's eight provinces. A foreign legal expert has been engaged to help draft the training curriculum and to monitor the development of the new primary courts. The grant will also cover research aimed at fusing customary and common law into a unified legal system.

The Foundation also made a one-year grant of U.S. $\$ 80,000$ to enable the Ministry of Public Affairs to bring home highly-trained expatriate black Zimbabweans needed for senior civil service posts.

Since independence in 1980 several new government ministries have been created to address Zimbabwe's major problems of rehabilitation and reconstruction and to begin social and economic development programs. Well-trained professionals are urgently needed, particularly since many white senior civil servants have left the country. The grant will cover the costs of repatriating some fifteen professional administrators at the level of assistant secretary or higher, and for such experts as economists, scientists, and engineers.

These two Foundation actions are the first in what is expected to be a broader program of support for Zimbabwean development.

\section{LAW AND ECONOMICS BIBLIOGRAPHY}

A new series entitled Bibliography in Law and Economics, bringing together references in major areas of Law and Economics research, was initiated recently by Cento Veljanovski, Centre for Socio-Legal Studies, Wolfson College, Oxford, England. "Contract Analysis" and "Legal Liability and Negligence," the first two bibliographies in the series, are already completed and available by writing the Centre. Professor Veljanovski is soliciting unpublished manuscripts, working papers, and research reports which may be included in future and revised versions. Already in progress are bibliographies of accident law, property rights, crime and criminal law, legal services and judicial procedure, family law, and regulation. The series is certain to provide a valuable service for Law and Economics researchers who may also look forward to seeing it consolidated into one reference volume in the future. 